\title{
An evaluation of the Church of Central Africa Presbyterian General Assembly and poverty alleviation from a koinōnian perspective in Malawi
}

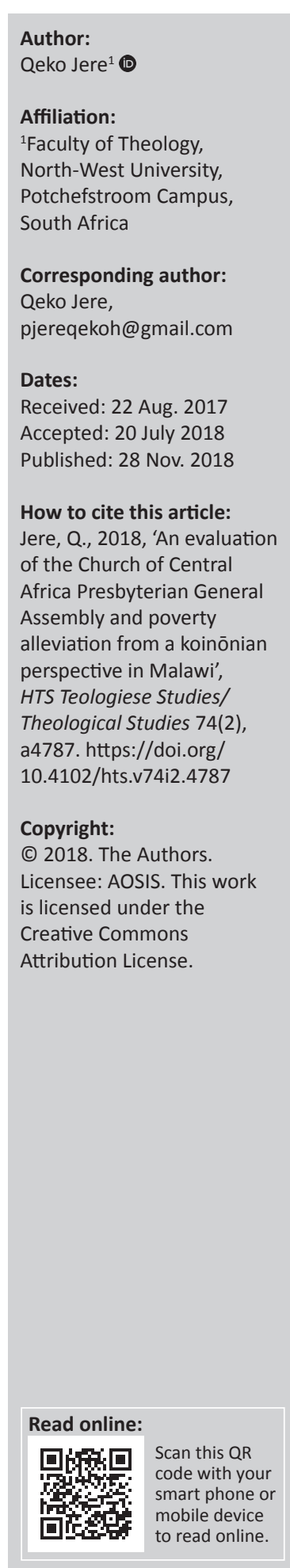

This article argues that the adoption and practice of koinonia is critically important to the poverty alleviation process. Koinonia empowers, as both the poor and the rich exist in the other and for the other, modelled on the immanent and economic Trinity. Koinonia is the very engine of the Godhead and the heart of a Christian gospel. It was the enforcement and institutionalisation of koinonian practice that contributed to the growth of the early church despite the economic hardship of the time. The lack of church koinonian life today has led to socio-economic disparities amongst congregations and congregants. This article aims at finding out whether the Church of Central Africa Presbyterian General Assembly (CCAP-GA) is a koinōnian community. This article evaluates the koinonian life in the CCAP-GA as a way of making the church an effective koinonian community. Thus the article examines whether there has been Presbyterian fellowship and koinōnian practice within the CCAP-GA. This article is informed by koinonian theoretical practice in probing the question of poverty within the CCAP-GA. Until the church and Christians begin to live and practise koinonian life, equally share and give at all levels, poverty will continue to be a challenge in the home, society and the church.

\section{Introduction and background}

Poverty is undoubtedly one of the major constraints to any form of development (Ondari 2001:1-2). In sub-Saharan Africa poverty remains stubbornly and unacceptably high (Zukang 2009:iii). In Malawi today, out of 17.2 million people (World Bank 2017), half of the population (8.6 million) experiences relative poverty, while a quarter ( 4.3 million) of the population suffers from ultrapoverty conditions. Individuals with ultrapoverty status live on less than $\$ 1$ a day, resulting in the inability to meet the barest of basic needs (Mushani \& Doctor 2014:704). As one of the poorest nations, Malawi ranks 151st out of 195 countries on the Human Development Index for 2010 (World Bank 2016). Malawi has an agro-based economy, where $85 \%$ live in rural areas while $15 \%$ live in urban areas, respectively (CIA Fact Book 2017; NSO-IHS3 2012:207). In 2016, the country's gross domestic product (GDP) reached $\$ 5.442$ million, with a GDP per capita of $\$ 481.527$ million (NSO-3IHS 2012:203-204; World Bank 2016).

The recent Third Integrated Household Survey commissioned by the National Statistical Office (2010-2011) shows that the Southern Region of Malawi has the largest poverty rate (63\%), followed by the Northern Region (60\%) and finally the Central Region of Malawi (49\%) (NSO-IHS3:204). The survey further indicates that, nationally, $57 \%$ of the rural population are poor, while $17 \%$ of the urban population are poor, too (NSO-IHS3 2012:204). Further data reveals that $25 \%$ of Malawians live in ultrapoverty, out of which $34 \%$ are from the rural Southern Region, followed by the Northern Region (29\%) and finally the rural Central Region (22\%) (NSO-IHS3 2012:209). Since the birth of pluralistic politics in 1994, the government and other stakeholders have tried various strategies for poverty reduction, including the Malawi Economic Growth and Poverty Alleviation strategy in 1994 (Mussa 2014:138), the Malawi Poverty Alleviation Program of 2002 (Bwalya et al. 2004:10), the Malawi Growth and Development Strategy I 2006-2011 (Muthalika 2007:iii), the Malawi Growth and Development Strategy II from 2011 to 2016 and the Malawi Economic Recovery Plan 2012-2014 (Malawi Government 2012).

Having explored the nationwide poverty situation and its demographic variations, it must be noted that the pandemic also hugely impacts on the Church of Central Africa Presbyterian

Note: This article is published in the section Practical Theology of the Society for Practical Theology in South Africa. 
General Assembly (which in this paper will be referred to as the CCAP-GA) because members are located within both the rural and urban centres across the country. This creates a link between national poverty and the church, where each affects the other (Norcia \& Rissotto 2013:180 183). By 2015, Presbyterian membership (CCAP) reached $27 \%$ nationally, with membership having increased to $30 \%$ by 2017 (CIA Fact Book-Religion 2017). The Northern Region's population of 2.2 million people has close to a million CCAP faithful, while in the central region, with a population of 7.2 million people, more than 1.5 million belong to the CCAP family. The Southern Region has a population of about 7.8 million people, of which more than 2 million people belong to the CCAP (Kamwendo 28/5/17; Munthali 27/5/17). Because more than half of the Malawi population live in abject poverty, the entire CCAP family is affected, because it is in these poverty-stricken areas where members live.

In an attempt to address poverty, the CCAP-GA has contributed, albeit on a smaller scale, by initiating communitybased projects at grassroots. However, inasmuch as there have been such efforts, little has been seen from the church's contribution at both national and local level as the gap between the rich and the poor continues to widen (Jere \& William 2016:59-69). This has been a result of lack of serious poverty alleviation at a local level, which when effectively done leads to the alleviation of poverty at a national level. In addition this has been the result of the application of secular approaches in poverty alleviation within the CCAP-GA family, which has hugely contributed to the church's failure. Now, would the shift from secular to Christian-based approaches add any value to the effective eradication of poverty and promotion of Presbyterian fellowship within the CCAP-GA?

This article is informed by koinōnian theoretical framework in dealing with the question of poverty within the church in the promotion of a life of equal sharing. Koinōnia originates from God himself (Kariatlis 2012:51) and from its original Greek; the verb koinoneo means 'to share, to participate and to have something in common' (Breed \& Simenya 2015:6; Fuchs 2008:7). Allen and Ross (2012:115) indicate that the Greek adjective koinonos denotes a 'companion, fellow or participant', while for Daniels (2007:211) the word koinonikos means 'to give generously and willingly'. Koinōnia is a gift from God to mankind (Oldewage 2014:30-32) and plays a critical role in the life of the church (Kariatlis 2012:54). Kärkkäinen (2007:4) summaries that koinōnia is about sharing, participation, communion and fellowship with an overarching focus on communion at the spiritual, social and even material level. Magezi (2006:506-509) explains that koinōnia must be more than just a mere communion and fellowship but that this must be the character and action of a faith community - that is, to make koinonia a lifestyle that would manifest through communion and equal sharing.
The application of koinōnia is viable because this doctrine is biblical, theological and scripturally based (Ac 2:44; 4:32; 33-35) and has greatly contributed to the life and growth of the Christian church throughout history. Biblically, the Old Testament depicts koinōnia in the fellowship between God and the Israelites through creation and Adamic narratives (Höring 2013:49). Kariatlis (2011:4-5) and Kim (2011:30) agree that it was because of koinōnia that a deep sense of community and fellowship was encountered in the New Testament church. For Kariatlis (2011:xi), the understanding of the church is closely connected to an understanding of God himself, whose life is koinōnia.

Koinonnia was enforced for the first time through the ministry of the early church, where congregants equally shared and distributed the available local resources in that everything they had was common (Ac 2:42-47; 4:32-37). Koinōnian practice entails that there was no poverty because nobody owned more than others; anything that anybody had was equally owned by the entire congregation. The purpose of practising this art of equal sharing was to avoid a situation of poverty amongst church members and to make sure that no one stayed hungry while others lived in plenty. Now the question is, how far has the CCAP-GA practised koinonian life as a way of demonstrating and emulating the koinonian life of God within himself and that of Christ and the early church for the empowerment of the poor?

However, the outstanding challenge is that although the CCAP-GA meets and shares in the fellowship as the body of Christ, there isn't a genuine life of inter-synodical sharing at leadership and local levels. That the church continues to have the poor in its midst is sign enough that those who are rich within the CCAP-GA are not able to equally share and empower the poor. Unless serious institutional and systematised koinonian life is practised within the CCAPGA, poverty and the congregational gap between the poor and the rich will continue to increase.

This article argues that emulating the New Testament koinōnian practice within the CCAP-GA would go a long way in helping make the church a koinōnian community with a full demonstration of love through a life of equal sharing, where the rich would live in total support of the poor's economic empowerment. This article therefore seeks to evaluate whether there has been Presbyterian fellowship and koinonia in the CCAP-GA. The Presbyterian communion, fellowship and koinōnia is examined within a koinōnian theoretical framework, which is viably presented to appreciate the life of fellowship within the Being of God, which is our paradigm, and the action that would lead to a complete transformation in the lives of the people in the church, and in this case the CCAP-GA.

\section{Koinōnian theoretical framework in poverty alleviation}

The Christian doctrine of koinōnia is one of the most outstanding theological dogmas that properly represents 
the life and unity of God and its value to the ecclesia (Zizioulas 1985:134). This theological dogma is the central theme and essential aspect found in the Vatican's 11 documents (McDonnell 1988:400) and many Christian ecumenical bodies (Heim 2004:9-10). Both Western and Eastern theological scholars agree with the significance of Trinitarian communion fellowship, which is koinōnia (Harkianakis 2008; Kariatlis 2012; LaCugna 1991; Zizioulas 1994). According to Zizioulas (1994:104), this concept of fellowship in communion is derived not from sociological experience but from faith in God, whose very being is koinōnia. For Liddell and Scott (1996:968), koinōnia denotes something that is held in common from which all can benefit.

This theological doctrine of koinōnia is founded on God (Elohim), who is one God (Gn 1:1) and equally exists in the Trinitarian Persons of the Father, Son and the Holy Spirit (Lossky 1957:55-56). According to Kariatlis (2012:53) koinōnia demands a complete fellowship, communal-ship sharing, communion, partnership. From whichever theological angle (Augustine's divine essence or Cappadocian's Trinitarian Persons) (Rostock 2010:32), because of the one nature or ousia, the Persons of the Trinity equally share koinōnian life (Hanson 1988:74), while at the same time maintaining their distinctiveness and equality as they each empty and dwell in the other (Ware 2012:32-33). Fuchs (2008:26), however, states that there is equal sharing within the Trinity, which is critical in understanding Christian koinōnia, where each of the three Persons encounters the others in freedom with its own unique character, identity as the divine Persons enter into communion and dwell in each other (Oldewage 2014:30).

\section{Theocentric vertical koinōnia: A love-focused Augustinian communion}

Theocentric vertical koinōnia is the art of communion and sharing that has its foundation in God and a direct fellowship with the divine. This communion is referred to as 'Augustinian koinōnia' because it's the type of sharing and love that originates from God the Father as the source. Augustinian koinōnia is translated and divinely connected to the fellowship as well as the intersharing that individuals have through their participation in the Holy Communion, worship, baptism and prayer (Kärkkäinen 2007:9-10). The Augustinian koinōnian paradigm has a centralised focus with the Father as the source, the principium, primary and the beginning of the deity and the cause of the Trinitarian koinonian love within the Trinitarian community (Kärkkäinen 2011:129). Critical to this application of Augustinian koinōnia is to understand how matters of church disparities within the CCAP-GA should be addressed. In line with Augustinian koinōnia, where the father is the source and the cause, the rich in the CCAP-GA would put enough resources in support of the poor while the poor would welcome with love and receive from the rich, thereby fulfilling koinōnian demands for equality. Just like the Father is the source and the cause according to Augustinian koinōnian concept, the rich have to initiate the process.

Critical for Augustine was the Holy Spirit, who he also called 'love', which facilitates the unity of the Godhead (Ratzenger 1998:327-328) and enhances the eternal generation of divine love, which binds us all together (Kariatlis 2012:55). Through communion, eternal divine fellowship and love, the Persons of the Trinity empty into each other and allow each other to exist in the other and for the other sharing koinonian life (Kariatlis 2012:54). For Augustine, the spirit that unites us through love (Hopkins 2006:225) is the same spirit that unifies the Father and the Son, becoming the reference for communion (Rostock 2010:323). Barnes (1999:154) tentatively states that the Father does not do anything that the Son and the Spirit do not also do; the Holy Spirit does not do anything that the Father and the Son do not also do; the Son does not do anything that the Father and the Holy Spirit do not also do. Through love, the distinctive relationship governs the entire Trinitarian system, such that in their unity they equally share the bond of koinonia (Kärkkäinen 2011:128-130).

Davis (2007:53) argues that in any relationship, the main issue is having the full scope and depth of the vertical relationship with God, who is the very source and definition of koinonia. Therefore, a good vertical relationship is critical and the very foundation in creating a positive view in dealing with koinōnia horizontally in the context of the church and one's fellow humans. At the same, a bad vertical view of God automatically creates a challenge in koinōnian life. Therefore, koinonia with each other becomes the very condition of our participation in the divine life (Heim 2005:196).

\section{Christocentric horizontal koinōnia: A Cappadocian communion}

We define Christocentric horizontal koinōnia as the art of sharing and generous fellowship that exists in society and community amongst people. This is the interpersonal communal life and an expression of Africanness and ubuntu (Magezi 2006:514), where Christians' existence depends on others (Breed \& Simenya 2015:1-2). This Christocentric horizontal koinōnia is Cappadocian in that the Trinitarian unity in the Person is equally shared within the Trinitarian Persons (Ware 2012:28-29). Moreover, it is because the Cappadocian unity is in the Trinitarian Persons, where the Father is the source, cause and the very principal of the entire Trinitarian relation (Lossky 1976:58-59).

This Christocentric horizontal koinōnia is modelled on the economy of God (economic Trinity) intimately through Christ and the Holy Spirit, who are equal within the Trinitarian framework (Marmion 2004:105). Economic Trinitarian life extends to the life of the church; as alluded by Kinnamon and Cope (1997:88-92), the church is not merely an institution or organisation but a fellowship of those who are called together by the Holy Spirit, in baptism confess 
Christ as their Lord and Saviour, and are fully committed to God and one another. Zizioulas (1985:17-18) contends that through incarnation, Christ created a strong horizontal fellowship, where his life and suffering manifest the interpersonal and relational nature of his existence. Christians participate in and promote unity and equality within the body of Christ. It is this collective and regular participation that enhances koinōnia within the church, Christian community and amongst individuals (Mbaya 2012:6). This equal sharing is contrary to subordinationism and monarchism and is translated into koinōnian intimacy with others (Kinnamon 2015:3). Moltmann (2010:38) states that the Trinity, which is the community of the Father, the Son and the Holy Spirit, does not promote any form of dominance but only communal love through fellowship in koinōnia.

\section{Church of Central Africa Presbyterian General Assembly historiography and Presbyterian communion}

The establishment of the CCAP cannot be discussed outside Dr Robert Law's vision for a united Presbyterian fellowship within Central Africa (Bolink 1967:191). The creation of the CCAP was motivated and initiated by two Scottish missions, the Livingstonia Mission in Northern Nyasaland and the Blantyre Mission in the south (Hokkanen 2015:81-82), and the Nkhoma Mission joined later. It was out of these three mission stations that the first presbyteries were created; Livingstonia in 1899, Blantyre in 1902 and Nkhoma in 1912 (Chilenje 2007:2). These three founding CCAP Presbyterian Synods in Malawi are the main focus of this study. In understanding and examining the significance of the union and fellowship, the CCAP presbyteries, General Synod and the CCAP-GA are examined with reference to the four steps that were taken in their establishment.

The first step toward the formalisation of this Presbyterian fellowship and communion was a change from individual missions to a joint Presbyterian system called the CCAP. Chilenje (2007:27), however, indicates that by 1893, Dr Robert Laws had a vision of a unified Presbyterian Church in Central Africa, joining forces with others such as Alexander Hetherwick of the Blantyre Mission and William Murray of the Nkhoma Mission (Minutes, CCAP Synod, 17-22/09/ 1924:4; Minutes, CCAP Synod 13-15/10/1926:4). According to Ross (1996a:174), by 1900 the journey leading to the formation of the church presbyteries, the CCAP and the CCAP General Synod finally commenced. Mapala (2016:72) adds that it was at the 1904 Blantyre missionary conference that the first definite discussions on the matter of church union took place. The whole proposal to have the CCAP union was agreed to and was formally institutionalised at the 1910 Mvera missionary conference (Thompson 1995:211).

The second step toward a complete Presbyterian fellowship and union was the official establishment and launch of the
CCAP in 1924 (Ross 1996a:193-194). The Dutch Reformed Mission's Nkhoma Presbytery joined later. As a result of world war and the Scottish Church's delay in endorsing the CCAP union, it was only in 1914 that this final approval to the union was given (minutes, CCAP Synod 17-22/9/1924:2). The CCAP was finally formalised and institutionalised in 1924, at a meeting held at Livingstonia (minutes, CCAP Synod, 17th-22/9/1924:4). At the launch, Rev. Alexander Hetherwick was elected the chairperson of the meeting (Minutes CCAP Synod, 17-22/9/1924:5), while Rev. Dr Robert Laws was elected the first moderator of the newly formed CCAP (Laws 1934:143). Two years later, in 1926 at the 50th anniversary of the establishment of the Blantyre Synod, the Nkhoma Mission joined the CCAP partnership, communion and union to become a synod (Thompson 1995:80). This union was significant in unifying the Presbyterian body in Malawi and promoting the spirit of fellowshipping and Presbyterian communion. It also enabled African ministers and elders to see themselves as part of the larger ecclesiastical body (Thompson 1995:79-80).

The third step toward a complete Presbyterian communion, partnership and union was the creation of a framework to govern and unify the operation of the three synods in Malawi, called the CCAP General Synod in 1956. From 1924 to 1956, the synods functioned independently of the other. However, by 1956, a draft constitution leading to the genesis of the CCAP General Synod was approved at a meeting that took place in Nkhoma in 1926 (Minutes, CCAP General Synod, 25-29/4/1956:7-8), constituting the General Synod of the CCAP.

The final step was the shift from the CCAP General Synod to the CCAP-GA in 2002, to effectively deal with current issues (Minutes, CCAP General Synod 1-5/9/2000:40-41). By 2000, the General Synod formed the General Synod Standing Committee to compile a new policy document and constitution for the Synod (Minutes, CCAP General Synod 1-5/9/2000:8-9). On 08 November 2002, the new constitution was adopted and the CCAP General Synod was renamed CCAP-GA (Minutes, CCAP General Assembly Constitution, 08 December 2002:15-16). Thus, on 08 November 2002, the CCAP-GA became the highest court of the church of all five CCAP synods, with executive power to address the various issues affecting the church (Munyenyembe \& Hofmeyr 2016:2). This was the realisation of the Presbyterian koinōnia, sharing and fellowship as designed by the church fathers in Malawi.

The 61 years of the CCAP-GA's existence (General Synod-1956 to General Assembly-2017) show the seriousness and commitment in fulfilling the original goal of having the united Presbyterian Church in Malawi. However, there have been some challenges within the CCAP-GA ecclesial system that have negatively affected the governance and leadership of the General Assembly. For instance, the distinct originality of the synod's territorial establishment has led to serious border wrangles between the synods (Mapala 2016:1-7); the 
clergy deployment system (particularly the Blantyre and Livingstonia Synods unlike Nkhoma Synod) has created dissatisfaction amongst clergy as a result of favouritism and nepotism; and finally, internal confrontation exists within the CCAP-GA, as a result of synods tending to have opposing views on social, political and ecclesial issues, either in support of or against the government. For instance, Livingstonia is against the quota system, while the Blantyre and Nkhoma Synods do not come clear on the matter because of the political position of their regions; moreover, Livingstonia sharply criticises the government while the Blantyre Synod's position tends to be moderate. So, did this unification include the truly meaningful art of material sharing between the synods and amongst Christians? Did it include the external art of sharing and giving to those in want?

\section{Towards a critical examination of koinōnian practice in the Church of Central Africa Presbyterian General Assembly}

In examining koinōnian life within the CCAP-GA, the focus is on the Augustinian and the Cappadocian koinonian paradigm within a Trinitarian theoretical framework in order to understand the equality, unity and distinction of the Trinitarian Persons in relation to the synods. The aim of this investigation is to determine the impact of the aforementioned with the intention of empowering the synod and thereby making poverty a thing of the past.

\section{Church of Central Africa Presbyterian General Assembly and the Augustinian vertical koinōnia}

I define Augustinian vertical koinōnia as a theological concept born out of Augustine's interpretation and understanding of the Trinity, where for him the Father is the source, focus and unity of the Trinity (Kärkkäinen 2011:129; Ware 2012:28-30). Some scholars, like Berkhof (1996:56-58), Prestige (1936:237), Ratzenger (1998:325-330) and Needham (1997:143) allude to Augustine's position that the same essence of God equally belonged to the Persons of the Trinity, which reflects the vertical mutual sharing within the Persons of the Father, Son and the Holy Spirit. Now, how does the vertical dimension of koinonia influence CCAP-GA, what does CCAP-GA learn from the role of each of the Persons in the Trinity? And what would be the implication of this in relation to the CCAP-GA and koinōnia? To begin with, it must be noted that the success of any relationship depends on the mutual existence of vertical relationships, the results of which generate effective horizontal relationships. Now, poor horizontal relationships within society and the church show how bad the vertical relationships are. Thus the CCAPGA's vertical relationship and koinōnian life must be good so as to translate into workable and effective horizontal relationships. Just like the Father relates equally well with the Son and the Spirit, the CCAP-GA must emulate such Trinitarian actions and translate them into workable action for effective koinōnian sharing.
Along the same lines, though the Father is the source and the cause within the Trinitarian community, he uses his position not for dominance but service to others, which provides a different level of understanding of the Augustinian koinonnian life of sharing. This reflects the operative nature of the Trinitarian hierarchy, where life is not about dominance but equal sharing of koinōnian life. However, I support the notion of Augustinian monarchy where the definition of a monarchy is inclusive and involves the entire Trinitarian community in total communion and equality (Dunham 2005:69), which in this case would mean bringing both the rich and the poor to an equal footing as they depend on and are in full service to each other through love within the CCAP-GA.

Note that from an Augustinian perspective, equality of the Persons has eternal subordination (generation) and eternal procession in koinōnian love (Kärkkäinen 2011:129), distinctly manifesting in the Persons' economic operations (Wilks 1995:80). Of course, eternal generation and procession creates challenges of subordination within the Trinity, but I advance the notion that both processes explain the operational nature and do not disturb the substance that is equally within the Trinitarian Godhead. Now, would such a view promote absolute control of the rich over the poor? To this regard, it's the monarchical communion within the Trinitarian Godhead where koinōnian life would be equal amongst all the Persons that would promote equal sharing within the CCAP-GA and the entire church. Now, if within the Trinitarian community the Persons are distinct and equally share divine life, then by implication distinctive features would still be recognised within the CCAP-GA, where within their differences love would control the operational and governance system of the CCAP-GA to the point that the spirit of sharing and giving would prevail at all levels: the rich and the poor, educated and uneducated, young and old. At the same time, love would drive the CCAP-GA to exercise complete fellowship and equal sharing in promoting Presbyterian koinonia at both the local and management levels. This would mean the Blantyre Synod, Livingstonia Synod and Nkhoma Synod each existing in the other and unconditionally for the other, equally sharing Presbyterian koinōnia.

\section{Church of Central Africa Presbyterian General Assembly and the Cappadocian koinōnia}

Cappadocian koinonia is the life of giving and equal sharing, depicted and copied from the Cappadocian's advocacy of total equality of the divinity within the Persons (LaCugna 1991:169-170), which means that there is a continuous equal flow of koinonian life within the Trinity. Unlike the Augustinian koinonian advocacy, which focuses on one major source with the Father as the principal (Lossky 1995:172-173), Cappadocian koinōnia's focus moves away from the Trinitarian monarchy and is built on an interrelational and governance system of the Father, Son and Holy Spirit (Zizioulas 1975:407). Thus the implication of Cappadocian koinonia for the CCAP-GA would mean that there would be 
deep interrelational connections within the General Assembly in as much as they are distinct synods where the focus would be the larger picture of promoting presbyterial koinōnia within the ecclesial governance. It would be in their distinct differences that the Presbyterian relations and spirit of sharing would be enhanced. This would mean that in their equality each synod would depend on the other and would not exist in isolation but in mutual togetherness and complete relation. For the CCAP-GA, this would reflect the life of equal sharing described in Acts 2 and 4; just as in Acts everything was common to them all, likewise within the CCAP-GA, koinōnia would mean the creation of a big Presbyterian union within Malawi where all synods would go beyond their existence but remain in total unity and equality at every level of governance.

However, absolute division is evident within the CCAP-GA. Just like the Cappadocian theologians rejected any form of subordination and hierarchy in the Trinity (LaCugna 1991:245) and carefully balanced the relationship within the Trinity (Wilks 1995:73), so must the CCAP-GA be governed through love to promote koinonian life. Allowing the few rich elite to control the majority poor is not optimal, and an initiative of equal sharing by welcoming support through koinōnian love is necessary, because this would be in agreement with Acts 2 and 4 in terms of equality. Thus, through love, intersynodical koinōnia and communion could be enforced through the CCAP-GA, thereby fulfilling the great command to love your neighbour as you love yourself (Mark 12:30-31), which is realised in the art of equally sharing koinōnian life in the book of Acts 2 and 4 . The affinity between the Augustinian double procession (Gregory Nazianzen 35, col. 1073 A) and the Cappadocian single procession is the sense of divine responsibility within the Persons as they equally exist in the other and fulfil the divine mandate. Similarly, a sense of responsibility to each other between the rich and the poor within the CCAP-GA has to be cultivated, where the spirit of koinonia can exist by means of implemented modalities.

\section{Towards an effective koinōnia in the Church of Central Africa Presbyterian General Assembly}

There are a couple of actions that the CCAP-GA needs to take in order to enhance koinōnian life at different levels within ecclesial operation and the governance system so as to have good and effective progress in church ministerial development.

\section{Fostering personal koinōnia within the General Assembly}

Nurturing and practising personal koinōnia is vital and is the very foundation of the process of economically empowering the CCAP-GA and ordinary Christians. This exercise derives from the vertical relationship between God and man, which translates into noble, horizontal action between man and fellow man (Christenson 2015:14).
Because God is the foundation of koinōnia (Wood 2015:9), the same God transforms hearts, causing people to look at each other with a human heart, which is translated into action for the poor and the needy around. Thus, through the gospel of total transformation, the transformed hearts would initiate sharing and giving at an individual level because the richness thereof would flow and meet other dimensions inside and outside the General Assembly. This would mean having interfamily support, which would originate from every individual transformed heart for the betterment of all. Unless koinōnia and sharing begin at a personal level, it will be difficult for them to spread equally into other dimensions of life in support of the poor, and poverty will remain a challenge

\section{Encouraging interpersonal Christian koinōnia}

The interpersonal fellowship of communion, Trinitarian in nature, needs to be initiated at all levels. Wood (2015:10) contends that those with more should work toward facilitating development and growth for those around them. This is partnering and fellowshipping with those who are suffering and needy, which is a noble, Christian action (Griffiths 2015:41). Thus, those with more in Chimaliro; Kaning'ina; Katoto; Areas 3, 6, 9, 10, 11, 12, 14, 43, 47, Nyambadwe and Namiwawa should share in material fellowship with the poor and needy in Zolozolo, Masasa, Mgona, Ntandile, Ntopwa and Mbayani, amongst others. Just like Christ's personal sharing brought forth eternal hope and salvation for all (Jn 10:10), the CCAP-GA level of sharing should manifest hope to the hopeless as those in leadership become examples like Christ in the spirit of koinonian sharing (Phlp 2:5-8). This is in line with Apostle Paul (Rom 12:13), who encourages the saints to contribute to the needs of the poor first from within the house of God (Gl 6:10), participate in the lives of others (1 Cor 10:16) and partnership at all levels (Phlp 1:5).

\section{There must be institutional koinōnian life in the General Assembly}

The institutionalisation of koinōnian life would hugely contribute in reducing the gap between the rich and the poor within the General Assembly of the Presbyterian Church in Malawi. This would require the involvement of prominent members of the General Assembly by making koinōnia practical in improving the material condition of others through practical fellowship (Wood 2015:8). This would mean the synod leadership of Livingstonia, Nkhoma and Blantyre operating under the demands and stipulations koinōnia entails. True institutional giving must start from those in leadership positions. Unless leaders have followed the demands of the koinonia community, they may continue to lead with less concern for the poor, instead widening the gap more. Thus, it must be observed that effective individual synod koinōnia is a gateway to effective intersynodical koinōnian operation. The absence of such has been a result of lack of institutional koinōnia. 


\section{Initiation of intersynodical koinōnia life}

The equal sharing and fellowship between synods in the CCAP-GA would reflect the bond and love of Christ, where respective synods would provide support in the welfare of the others (Ac 2:42; 1 Jn 1:3; Rom 15:24-26.). For instance, the Blantrye, Nkhoma or Livingstonia Synods would support each other at all levels of existence, not only during national emergency situations but at all times. This would not be subordinating or subjecting the needs of synods on the other hand but would be a mutual and equal koinōnian sharing of Presbyterian love amongst the CCAP-GA, materially, emotionally and spiritually. Wood (2015:7) recommends such action of translating koinōnia into material provision for the needy, just like the generosity of the Macedonian and Achia Churches in the New Testament (2 Cor 9:1-15, Rom 15:26), even though were impoverished and poor themselves (Christenson 2015:14). The meagre support that is seen within the CCAP-GA during crisis shows and reveals selfishness, which goes against the spirit of koinōnia. For instance, when the 2015 and 2017 flood disasters struck the Blantyre Synod and Livingstonia areas in the south and north, meagre support came from within the CCAP-GA system. Unless there is a shift in terms of urgency from each synod in helping mitigate difficulties that each synod faces, the koinōnian spiritual flow within the synod shall always be unsatisfactory.

\section{Embracing koinōnia in unity in diversity}

Embracing koinōnia as a lifestyle within the CCAP-GA would be the other workable solution in promoting Presbyterian fellowship within the synod's differences. As has been alluded to, the sharp ecclesial differences, originality, locations, leadership elections and national advocacy would be accommodated and compromised within the equal sharing of koinōnian life, which would then unite the CCAPGA. The synod unity embedded in koinōnia would become synodical and effectively able to deal with all border, territorial and leadership conflict. Like the Trinitarian pattern, koinonnia would be the unifying link within the CCAP-GA Presbyterian framework, as the synods exist and live to share equally for the survival and sustenance of the other. Koinōnia, as the unifying link, would enhance mutual equality in the operation within their distinctive geographical locations north, central and south. While in the Trinity, the unity has either been in the substance (Augustinian) or Persons (Cappadocian), in the CCAP-GA the unity would be koinonnian, which would be the very life of God that equally flows and unites the synods for the sustenance of the entire CCAP-GA koinōnia life.

\section{Conclusion}

This article has engaged koinōnia as an approach and theoretical paradigm, the application of which leads to church and societal empowerment. In doing this, the article looked into Augustinian and Cappadocian koinōnia in relation to empowerment. In regard to this, the article emphasised that even though there are unique differences within the CCAP-GA, it is within similar differences that the koinōnia spirit of love and sharing would effectively enhance equality within the entire CCAP-GA. Based on the engagement of koinonia in this paper and how far the CCAPGA has come so far in dealing with the same, this article has submitted five main action plans that the CCAP-GA needs to take on as a way of promoting the life and practice of koinonnia within the ecclesia.

\section{Acknowledgements Competing interests}

The author declares that he or she has no financial or personal relationships which may have inappropriately influenced him or her in writing this article.

\section{References}

Allen, H.C. \& Ross, C.L., 2012, Intergenerational Christian formation: Bringing the whole church together in ministry, community and worship, Intervarsity Press, Downers Grove, IL.

Barnes, M.R., 1999, 'Rereading Augustine's theology of the Trinity', in S.T. Davis, D. Kendall \& G. O'Collins (eds.), The Trinity: An interdisciplinary symposium on the Trinity, pp. 145-176, Oxford University Press, Oxford.

Berkhof, L., 1996 (1938), Systematic theology, Eerdmans, Grand Rapids, MI.

Bolink, P., 1967, Towards Church Union in Zambia: A study of missionary cooperation and church union efforts in Central Africa, Franeker T. Wever, Franeker, Netherland.

Breed, G. \& Semenya, K., 2015, 'Ubuntu, koinōnia and diakonia, a way to reconciliation in South Africa?', HTS Teologiese Studies/Theological Studies 71(2), Art. \#2979, 9 pages. https://doi.org/10.4102/hts.v71i2.2979

Bwalya, E., Rakner, L., Svasand, L., Tostensen, A. \& Tsoka., M., 2004, Poverty reduction strategy process in Malawi and Zambia, Chr. Michelsen Institute, Bergen, Norway.

Chilenje, V., 2007, 'The origin and development of the Church of Central Africa Presbyterian (CCAP) in Zambia', unpublished DTh. dissertation, non published, Stellenbosch University.

Christenson, J., 2015, 'Koinōnia: The DNA of Gospel partnership', Mission Round Table 10(1), 12-15.

CIA Fact Book, 2017, Malawi: Office of the public affairs, Central Intelligency AgencyState Department, Washington, DC.

Daniels, K., 2007, Worshipping the one true God, Xulon Press, Maitland, FL.

Davis, C.M., 2007, City lights: Considering the value of an urban-suburban partnership through the lenses of social capital and koinōnia, Palmer Theological Seminary, Wynnewood, PA.

Dunham, S.A., 2005, 'The Trinity and creation: Augustine and Boff on monarchy, Governance and dominion', a PhD thesis submitted to Faculty of Theology, McMaster University, Hamilton, Ontario.

Fuchs, L.F., 2008, Koinōnia and the Quest for an Ecumenical Ecclesiology: From foundations through dialogue to symbolic competence for communionality, Wm. B. Eerdmans Publishing Company, Grand Rapids, MI.

Gregory Nazianzen, Oratio 20, De dogmate et constitutione episcoporum 7, P.G. tom. 35 , col. $1073 \mathrm{~A}$

Griffiths, M., 2015, 'Don't expect a fairy-tale ending: The realities of Biblical Partnership', Mission Round Table 10(1), 38-43.

Hanson, R.P.C., 1988, The search for the Christian Doctrine of God: The Arian Controversy 318-381, T. \& T. Clark Ltd., Edinburgh.

Harkianakis, S., 2008, The infallibility of the Church in Orthodox Ecclesiology, transl. Philip Kariatlis, ATF Press, St Andrew's Orthodox Press, Sydney.

Heim, M.S., 2004, Sharing our differences: Koinonia and the theology of religious plurality, Commission on Faith and Order, World Council of Churches, Zürich, Switzerland.

Heim, M.S., 2005, 'Witness to communion: A Trinitarian perspective of mission and religious pluralism', International Review XXXIII(2), 192-199. https://doi. org/10.1177/009182960503300205

Hokkanen, M., 2015, 'The government medical service and British missions in colonial Malawi, c. 1891-1940: Crucial collaboration, hidden conflicts', in A. Greenwood (ed.), Beyond the state: The colonial medical service in British Africa, pp. 39-63, Manchester University Press, Manchester.

Hopkins, J.P., 2006, 'The unity of the spirit: The Trinity, the church and love in Saint Augustine of Hippo', master of letter dissertation submitted to the Department of Theology and Religion, Durham University. 
Höring, P., 2013, 'Koinōnia: A Roman Catholic perspective on a theological pattern for Youth Ministry as a community', Journal of Youth and Theology 12(1), 46-57. https://doi.org/10.1163/24055093-90000060

Jere, Q. \& Williams, D.T., 2016, 'Examining the Kenosis of the CCAP Blantyre Synod in Poverty alleviation in Malawi', Theologia Viatorum 40(1), 43-67.

Kariatlis, P., 2011, Church as communion: The gift and goal of koinōnia, ATF Press and St Andrew's Press, Adelaide.

Kariatlis, P., 2012, 'Affirming koinōnia ecclesiology: An orthodox perspective', Phronema 27(1), 51-66.

Kärkkäinen, V.M., 2007, 'The church as the fellowship of persons: An emerging Pentecostal Ecclesiology of Koinōnia', PentecoStudies 6(1), 1-15.

Kärkkäinen, V.M., 2011, 'Is the spirit still the dividing line between the Christian East and West? Revisiting an ancient problem of Filioque with a hope for an Ecumenical Rapprochement', Perichoresis 9(2), 126-142.

Kim, T.H., 2011, 'Building up the church and church growth in Korean churches through the Koinōnia of a small group ministry', a master of theology dissertation, University of Pretoria, South Africa.

Kinnamon, M., 2015, 'Koinōnia and Philoxenia. Toward an expanded Ecumenical Ecclesiology', Ecumenical Trends 44(10), 1-5.

Kinnamon, M. \& Cope, B.E., (eds) 1997, The Ecumenical movement: An anthology of key texts and voices, Eerdmans, Grand Rapids, MI.

LaCugna, C.M., 1991(1994), God for us: The Trinity and Christian life, Harper Collins, San Francisco, CA.

Laws, R., 1934, Reminiscences of Livingstonia, Oliver and Boyd, Edinburgh.

Liddell, H.G. \& Scott, R., 1996, A Greek-English Lexicon, revised by Sir Henry Stuar Jones, 9th edn., with new supplement added, Clarendon Press, Oxford.

Lossky, V., 1957, The mystical theology of the Eastern Church, transl. the Fellowship of St. Alban and St. Sergius, James Clarke, London.

Lossky, V., 1976, The mystical theology of the Eastern Church, St. Vladimir's Seminary Press, Crestwood, NY.

Lossky, V., 1995, 'The procession of the Holy Spirit in orthodox Trinitarian theology', in D.B. Clendenin (ed.), Eastern orthodox theology: A contemporary reader, Baker Books, Grand Rapids, MI.

Magezi, V., 2006, 'Community healing and the role pastoral care to the ill and suffering in Africa', Die Skriflig 40(3), 1-17. https://doi.org/10.4102/ids.v40i3.356

Malawi Government, 2012, Malawi growth and development strategy, Ministry of Economic Planning and Development, Lilongwe.

Mapala, C.W., 2016, 'A historical study of the border dispute between the livingstonia and nkhoma synods of the church of central Africa Presbyterian (1956-2015- a1 \& c1)', Doctor of Philosophy thesis, College of Humanities, University of KwaZulu Natal.

Marmion, D. \& Van Nieuwenhove, R., 2012, An introduction to the Trinity, Cambridge University Press, Cambridge.

Mbaya, H., 2012, 'Friendships and fellowship: Living Koinōnia, Martyria and Diakonia in the Corinthian Church of South Africa from the Perspective of Social Capital', HTS Theological Studies 68(2), 1-6. https://doi.org/10.4102/hts.v68i2.1169

McDonnell, K.O.S.B., 1988, 'Communion ecclesiology and baptism in the spirit: Tertullian and the early church', Theological Studies 49, 671-693. https://doi. org/10.1177/004056398804900404

Minutes: CCAP General Assembly Constitution, CCAP General Assembly Headquarters, Area 18 Anglican Complex, Lilongwe, 8th December, 2002.

Minutes: CCAP General Synod, 1-5 November, 2000. Minutes of the 19th General Synod of the Church of Central Africa Presbyterian held at Blantyre CCAP Mission, 1-5 November 2000, General Synod Headquarters, Area 18 Anglican Complex, Lilongwe.

Minutes: CCAP Synod, 17-22 September 1924. The Church of Central Africa, Presbyterian. Minutes of first meeting of Synod, 17-22 September 1924. (DRCAABID), Livingstonia Synod, Livingstonia.

Minutes: CCAP General Synod, 25-29/4/1956: Minutes of first meeting of General Synod., Nkhoma Synod, Lilongwe.
Moltmann, J., 2010, 'God the Father in the Life of the Holy Trinity', International Journal of Orthodox Theology 1(1), 38-48.

Munyenyembe, R. \& Hofmeyr, J.W., 2016, 'Lofty but not powerful: A critical analysis of the position of the general assembly in the Union of the Church of Central Africa Presbyterian (Malawi)', Studia Historiae Ecclessiasticae 42(3), 1-21. https://doi. org/10.17159/2412-4265/2016/1244

Mushani, N. \& Doctor, H.V., 2014, 'Public expenditure and health status in the context of millennium development goals in Malawi', International Journal of Development and Sustainability 3(4), 702-714

Mussa, R., 2014, 'Household expenditure components and the poverty and inequality relationship in Malawi', African Development Review 26(1), 138-147. https://doi. org/10.1111/1467-8268.12070

Muthalika, B., 2007, Speech: Official launch of governance and corruption baseline report-development of anti-corruption action in the ACB: Draft workshop report, pp. 18-22, ACB Headquarters, Lilongwe.

Needham, N., 1997, 'The Filioque clause: East or west?', Scottish Bulletin of Evangelica Theology 15, 142-162.

Norcia, M. \& A. Rissotto, A., 2013, 'How religious faith affects beliefs on poverty: A study in Italy', International Journal of Social Science and Humanity 3(2), 180-185. https://doi.org/10.7763/IJSSH.2013.V3.223

NSO, 2012, The 3rd integrated household survey report, Statistical Office, Zomba.

Oldewage, H.E., 2014, 'Fostering koinōnia: A critical evaluation of the value of digital social networks in urban congregations', DPhil dissertation, Faculty of Theology, North-West University, Potchefstroom Campus.

Ondari, W., 2001, 'Poverty and wealth: A Christian perspective', A working paper for the 28th International Faith and Learning Seminar held at Babcock University, Ilishan-Remo, Ogun State, June 17-29.

Ratzinger, J., 1998, 'The Holy Spirit as communion. Concerning the relationship of Pneumatology and spirituality in Augustine', Communio 25(summer), 325-339.

Ross, A.C., 1996a, Blantyre mission and the making of modern Malawi, Assemblies of God Press, Limbe.

Ross, K., 1996b, Political theology of power for the new Malawi, CLAIM, Blantyre.

Rostock, N., 2010, 'Two different Gods or two types of unity? A critical response to Zizioulas' presentation of "The father as cause" with reference to the Cappadocian Fathers and Augustine', New Blackfriars 91(1033), 321-334. https://doi.org/ 10.1111/j.1741-2005.2008.00245.x

Thompson, T., 1995, Christianity in Northern Malawi, Donald Fraser's Missionary Methods and Ngoni Culture: Studies in Christian Mission, Leiden, New York.

Ware, B.A., 2012, 'Christian worship and taxis within the Trinity', Southern Baptist Journal of Theology 16(1), 28-42.

Wilks, J.G.F., 1995, 'The Trinitarian Ontology of John Zizioulas', Vox Evangelica 25, 63-88.

Wood, P., 2015, 'Perichoresis and Koinōnia: Implication of our fellowship with God for the changing missionary endeavor', Mission, Round Table 10(1), 4-11.

World Bank, 2016, Country report, Lilongwe, Malawi.

World Bank, 2017, Gross Domestic Product (GDP)-Malawi 2017-Malawi, World Development-Indicators database, World Bank, Lilongwe.

Zizioulas, J., 1994, 'The church as communion', in T.F. Best \& G. Gassmann (eds.), On the way to Fuller Koinonia: Official Report of the Fifth World Conference on Faith and Order, WCC, Geneva, August 3-14, 1994.

Zizioulas, J.D., 1975, 'Human capacity and human incapacity: A theological exploration of personhood', SIT 28(1975), 407-408.

Zizioulas, J.D., 1985, Being as communion: Studies in personhood and the Church, Darton, pp. 3-16, Longman and Todd, London.

Zukang, S., 2009, Rethinking poverty: Report on the world social situation 2010, Report, Department of Economic and Social Affairs, United Nation, New York. 